\title{
Number of buried seeds and seedlings emergence in cerradão, cerrado and gallery forest soils at Pedregulho, Itirapina (SP), Brazil
}

\author{
REGINA M. SASSAKI ${ }^{1}$, JOSIMARA N. RONDON ${ }^{1}$, LILIAN B.P. ZAIDAN ${ }^{1,2}$ and G.M. FELIPPE ${ }^{1,2}$
}

(recebido em 26/03/98; aceito em 2/01/99)

\begin{abstract}
Number of buried seeds and seedlings emergence in cerradão, cerrado and gallery forest soils at Pedregulho, Itirapina (SP), Brazil). This study was carried out at the site named Pedregulho in the "Estação Experimental de Itirapina", Itirapina, state of São Paulo, Brazil. Soil samples were collected in the rainy and in the dry season at three depths in the gallery forest, cerrado and cerradão. The total number of seeds was counted after being separated from the soil by wet sieving and the number of viable seeds was determined by emergence of seedlings in soil samples in a greenhouse. The number of seeds and of emerged seedlings decreases as soil samples become deeper. The number of seeds was much larger in the cerrado in the dry season than in the rainy season, but it was lower in the dry than in the rainy season in the gallery forest. The number of seeds in the cerradão was similar in both seasons. There was a heavy discrepancy between the total number of seeds and that of emerged seedlings.
\end{abstract}

RESUMO - (Número de sementes e emergência de plântulas em solos de cerrado, cerradão e mata ciliar em Pedregulho, Itirapina (SP), Brasil). O presente trabalho foi conduzido numa localidade denominada Pedregulho, na Estação Experimental de Itirapina, município de Itirapina, estado de São Paulo, Brasil. As amostras de solo foram coletadas na estação chuvosa e na estação seca, em três profundidades, em área de mata ciliar, cerrado e cerradão. Após separação do solo com uso de peneiras e água, foi contado o número de sementes e determinado o número de sementes viáveis através da emergência de plântulas em amostras de solos mantidas em casa de vegetação. O número de sementes e de plântulas diminui à medida que aumenta a profundidade do solo. Maior número de sementes foi observado no solo de cerrado na estação seca do que na estação chuvosa, porém na mata ciliar, o número de sementes foi mais elevado na estação seca. Em solo de cerradão, o número de sementes foi semelhante nas duas estações de coleta das amostras de solos. Houve uma grande discrepância entre o número total de sementes presentes nas amostras de solo e o de plântulas que emergiram.

Key words - Cerrado, cerradão, gallery forest, buried seeds

\section{Introduction}

The natural cover of about $25 \%$ of the land area of Brazil was savannah vegetation given the name of cerrado "sensu lato". The vegetation of many cerrado areas have been destroyed for agricultural purposes. Cerrado vegetation is floristically and physiognomically diverse. Although annual rainfall can be as high as $2000 \mathrm{~mm}$, much of the cerrado is subject to prolonged and often severe winter drought lasting for up to four months of the year (Eiten 1972). When the cerrado "sensu lato" presents a canopy cover of about $50 \%$ and the height of the stand is rarely greater than $18 \mathrm{~m}$ this cerrado is called cerradão and when presenting only scattered trees and shrubs to give a canopy cover of less than $2 \%$, it is called open-cerrado (Eiten 1972, Felippe \& Dale 1990). Trees and shrubs have a tortuous and gnarled appearance, especially when they have been exposed to fire. Many areas are subject of regular burning as

1. Research-fellow - CNPq

2. Instituto de Botânica, Caixa Postal 4005, 01061-970 São Paulo, SP, Brazil. part of their management for cattle rearing (Coutinho et al. 1982).

Soil-stored seed bank is widely used to indicate the reservoir of viable seeds in the soil and the surface of the soil (Roberts 1981). Weeds of abandoned fields, are effective in developing a seed bank. Many seeds that go through a period of dormancy might be incorporated as part of a soil seed bank. Thus the soil seed bank can be made of a transitory element includes most of the seeds of the surface of the soil, seeds capable to germinate straightaway - and a permanent component - seeds which will be viable for a number of years (Graham \& Hutchings 1988). In general, the persistent soil bank presents compact, smooth and small seeds which possess very precise mechanisms for breaking dormancy and in the temporary bank the seeds are large, flat and long and the conditions for overcoming dormancy are not very well defined (Thompson 1987). The soil seed bank is an important repository for the total plant species richness of a habitat (Berge \& Hestmark 1997). Quite often soil seed banks contain species of genotypes not found in the aboveground vegetation (Bennington et al. 1991). 
The seeds and fruits are extracted from the soil by physical methods based on size differences or diversity (Price \& Reichman 1987, Henderson et al. 1988, Benoit et al. 1989). Obviously the number of recovered seeds depends on the method used and studies comparing the results for estimating seed number obtained from different methods are few (Gross 1990, Brown 1992, Villiers et al. 1994). The number of viable seeds is estimated by placing samples of the soil in favourable conditions and following the germination and emergence of seedlings (Archibold 1981, Howe \& Chancellor 1983, Graham \& Hutchings 1988, Graström 1988, Coffin \& Lavenroth 1989).

Although soil seed banks have been well studied in temperate regions, the only paper published for Brazilian areas in an accessible international journal is that of Garcia (1995). Garcia (1995) studied the weed seed bank in a maize field at three depths and the results point to a tendency of tropical cultivated soils to have smaller seed banks than in temperate regions.

The objective of this work was to find out if a seed bank is present in a natural area of cerrado (cerrado and cerradão) and if so, how it compares with seed bank in the gallery forest in terms of density of seeds and number of viable seeds. The work also addresses another question: do the seeds have an even distribution in the soil profile in the three areas studied? In this paper only seed number and seedling emergence were dealt with to show the presence or absence of seed banks, thus a study in terms of species occurring was not aimed at.

\section{Material and methods}

The present study was carried out in the Estação Experimental de Itirapina, Itirapina, state of São Paulo, Brazil (Pedregulho site). A floristic survey of this area was previously carried out and a total of 118 species of angiosperms, 87 genera and 26 families were sampled. The climate of the region is mesothermic, with a dry winter, presenting an annual water deficit of $23 \mathrm{~mm}$ (Gianotti \& Leitão Filho 1992). The soil samples were collected in three areas: gallery forest, cerrado "sensu stricto" and cerradão at depths of 0-5, 5-10 and 10-15 cm. The chemical and physical analyses of these samples (one replicate of each) are presented in tables 1 and 2. The samples were collected in the dry (beginning of August 1996) and rainy (end of February 1997) seasons. Figure 1 presents the rainfall and the temperature of the region over the period in which the soil samples were collected.

Three replicates of the soil were collected with a $5 \mathrm{~cm}$ deep metal square $(25 \times 25 \mathrm{~cm})$ for each depth in the three areas (thus nine samples for each area). The soil of the three replicates was placed in a tray and after being thoroughly homogenised a sample of $500 \mathrm{~cm}^{3}$ (thus only one replicate was counted) was taken for the separation of the seeds (means always seeds and fruits) through a wet sieving treatment. Wet sieving was carried out with tap water and sieves with $2.00,0.85$ and $0.42 \mathrm{~mm}$ pores. The sieves were mounted in a shaker (Test sieve shaker EFL1 mk3, Endecott) and the filtration lasted for 30 minutes. Before sieving 500 seeds of Celosia cristata (L.) O. Ktze (an exotic species) were added to the soil sample and thoroughly mixed in to serve as a marker in all the samples used. For the dry season the tap water used in the wet sieving was collected and decanted for 24 hours; the water was then discarded and the soil was placed in trays in a greenhouse to check if seeds smaller than $0.42 \mathrm{~mm}$ were present. This was verified through the emergence of seedlings over a period of time. After the wet sieving, the material retained in each sieve was left to dry at room temperature and then dry sieved. Seeds and fruits were separated manually from the material left in each sieve. For the material in the $0.42 \mathrm{~mm}$ sieve a stereomicroscope was used to separate and to count the seeds.

Samples of $200 \mathrm{~cm}^{3}$ of soil were used for the observation of emergence of all seedlings. As soon as the seedling appeared over the surface of the soil it was considered emerged. In trays of 22 $\mathrm{cm}$ diameter and $3 \mathrm{~cm}$ deep a thin layer of wet sterilised sand was placed. A layer of $0.5 \mathrm{~cm}$ of soil was placed over the sand: due to light sensitive seeds the layer of soil should be thinner than $1 \mathrm{~cm}$, as recommended by Wesson \& Wareing (1969). The trays were covered with transparent film and kept all the time in a greenhouse, where the sunlight was cut by $50 \%$ ("sombrite"). Enough water to keep the soil always wet was added daily and the transparent film was changed when needed. One tray was used for each collected sample (three areas and three depths). All emerged seedlings (no distinction was made between normal and abnormal seedlings) were counted up to 83 days from the beginning of the experiment.
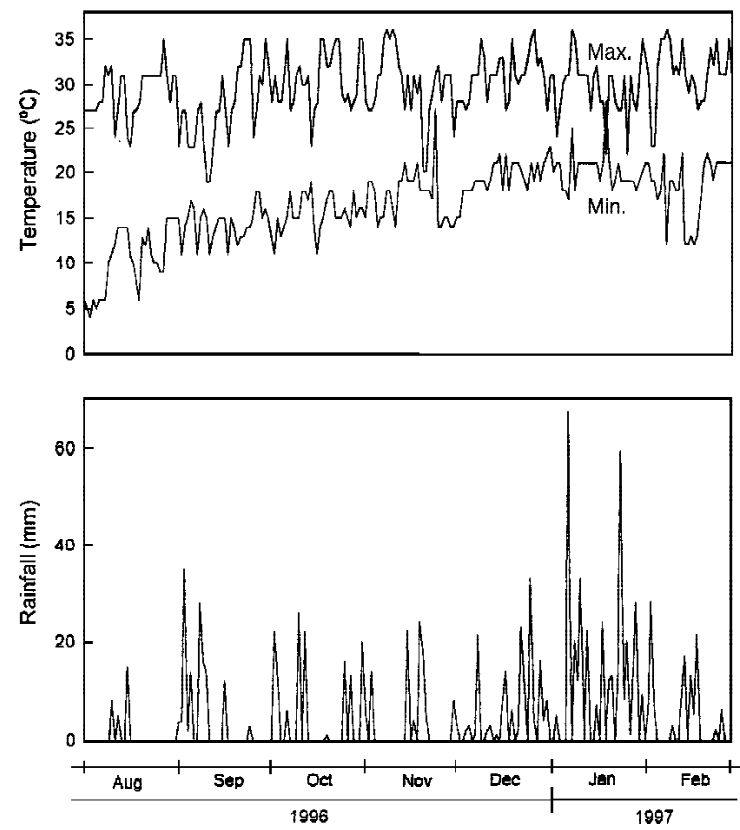

Figure 1. Temperature $\left({ }^{\circ} \mathrm{C}\right)$ and rainfall $(\mathrm{mm})$ during the period of the experiments carried out at Pedregulho (Estação Experimental de Itirapina) Itirapina, São Paulo, Brazil. 
Table 1. Chemical analysis of the soil samples from Pedregulho, Estação Experimental de Itirapina (Itirapina, São Paulo, Brazil), according to the Departamento de Ciências do Solo, Universidade de São Paulo, Piracicaba, SP.

\begin{tabular}{|c|c|c|c|c|c|c|c|c|c|c|c|c|c|}
\hline \multirow{2}{*}{ Sample } & \multirow{2}{*}{$\begin{array}{l}\text { Depth } \\
(\mathrm{cm})\end{array}$} & \multirow{2}{*}{$\begin{array}{c}\mathrm{P}_{\mathrm{resin}} \\
\left(\mu \mathrm{g} \cdot \mathrm{cm}^{-3}\right)\end{array}$} & \multirow{2}{*}{$\begin{array}{l}\mathrm{OM} \\
(\%)\end{array}$} & \multirow{2}{*}{$\begin{array}{c}\mathrm{pH} \\
\mathrm{CaCl}_{2}\end{array}$} & $\mathrm{~K}^{+}$ & $\mathrm{Ca}^{2+}$ & $\mathrm{Mg}^{2+}$ & $\mathrm{Al}^{3+}$ & $\mathrm{H}^{+}+\mathrm{Al}^{3+}$ & $\mathrm{SB}$ & CEC & $\mathrm{V}$ & $\mathrm{m}$ \\
\hline & & & & & \multicolumn{7}{|c|}{ meq. $100 \mathrm{~cm}^{3}$} & \multicolumn{2}{|c|}{$\%$} \\
\hline \multirow[t]{3}{*}{ Cerrado } & $0-5$ & 9 & 4.9 & 3.6 & 0.19 & 0.5 & 0.4 & 1.4 & 10.9 & 1.1 & 12.0 & 9 & 56 \\
\hline & $5-10$ & 6 & 3.0 & 3.8 & 0.15 & 0.2 & 0.2 & 1.2 & 8.8 & 0.6 & 9.4 & 6 & 67 \\
\hline & $10-15$ & 4 & 2.5 & 3.9 & 0.16 & 0.1 & 0.2 & 0.7 & 8.0 & 0.5 & 8.5 & 6 & 58 \\
\hline \multirow[t]{3}{*}{ Cerradão } & $0-5$ & 5 & 1.4 & 4.2 & 0.27 & 0.4 & 0.4 & 0.3 & 2.2 & 1.1 & 3.3 & 33 & 21 \\
\hline & $5-10$ & 2 & 1.3 & 3.9 & 0.13 & 0.3 & 0.3 & 0.7 & 2.8 & 0.7 & 3.5 & 20 & 50 \\
\hline & $10-15$ & 3 & 1.0 & 4.0 & 0.08 & 0.2 & 0.2 & 0.4 & 1.8 & 0.5 & 2.3 & 22 & 44 \\
\hline Gallery & $0-5$ & 20 & 6.7 & 4.1 & 0.35 & 3.6 & 1.9 & 1.1 & 13.5 & 5.9 & 19.4 & 30 & 16 \\
\hline \multirow[t]{2}{*}{ forest } & $5-10$ & 20 & 5.7 & 3.9 & 0.25 & 1.3 & 0.8 & 2.0 & 15.0 & 2.4 & 17.4 & 14 & 45 \\
\hline & $10-15$ & 19 & 4.7 & 3.9 & 0.11 & 0.5 & 0.3 & 2.2 & 13.5 & 0.9 & 14.4 & 6 & 71 \\
\hline
\end{tabular}

OM: organic matter; $\mathrm{H}^{+}+\mathrm{Al}^{3+}$ : potential acidity; $\mathrm{SB}$ : sum of bases $=\mathrm{Ca}^{2+}+\mathrm{Mg}^{2+}+\mathrm{K}^{+}$; CEC: cationic exchange capacity $=\mathrm{SB}+$ $\left(\mathrm{H}^{+}+\mathrm{Al}^{++}\right) ; \mathrm{V}$ : saturation of bases $=\mathrm{SB} . \mathrm{CEC}^{-1} .100 ; \mathrm{m}$ : saturation of $\mathrm{Al}^{3+}=\mathrm{Al} .(\mathrm{SB}+\mathrm{Al})^{-1} .100$

\section{Results}

The method used for separating seeds from soil was considered very effective as nearly all the seeds of Celosia cristata (97\%) were recovered independently of the soil used.

Number of seeds and emerged seedlings in the soil bank in the dry season - The number of seeds in the soil samples collected in the dry season at Pedregulho is shown in table 3 . The cerrado soil is very rich in seeds while in the cerradão and in the gallery forest the number is small when compared to that of the cerrado. The cerrado presents a clayey soil whereas the cerradão a more sandy type of soil (table 2). The number of seeds decreases with increasing depth in the cerrado, cerradão and gallery forest. In cerrado the majority of seeds are small, being retained in the $0.42 \mathrm{~mm}$ pore sieve (three times more seeds than in the other two sieves). The gallery forest soil also presents more small seeds than larger ones. The picture is different for the cerradão: more seeds were retained in the $0.85 \mathrm{~mm}$ pore sieve. Few seeds larger than $2.00 \mathrm{~mm}$ were present in the three soil banks. The total number presented in table 3 accounts for most of the seeds in the bank, as the number of seeds smaller than $0.42 \mathrm{~mm}$ were not counted. This is because during wet sieving the few smallest seeds were not retained by the $0.42 \mathrm{~mm}$ sieve.
The soil that went through the $0.42 \mathrm{~mm}$ pore sieve was placed in trays (three replicates) and the emerged seedlings were counted. Very few seedlings emerged. No seedlings appeared in the soil from the gallery forest; nine seedlings of dicotyledons were collected in the soil from the cerrado; three dicotyledon seedlings and one monocotyledon species were present in the cerradão soil.

Table 2. Physical analysis of the soil samples from Pedregulho (Itirapina, São Paulo, Brazil, according to the Departamento de Ciências do Solo, Universidade de São Paulo, Piracicaba, SP.

\begin{tabular}{|c|c|c|c|c|c|c|c|c|c|c|}
\hline \multirow{2}{*}{ Sample } & \multirow{2}{*}{$\begin{array}{c}\text { Depth } \\
(\mathrm{cm})\end{array}$} & \multicolumn{6}{|c|}{ Sand (\%) } & \multirow{2}{*}{\multicolumn{2}{|c|}{$\begin{array}{l}\text { Silt Clay } \\
(\%)(\%)\end{array}$}} & \multirow{2}{*}{$\begin{array}{c}\text { Texture } \\
\text { class }\end{array}$} \\
\hline & & $\mathrm{vc}$ & $\mathrm{c}$ & $\mathrm{m}$ & $\mathrm{f}$ & $\mathrm{vf}$ & tot & & & \\
\hline \multirow[t]{3}{*}{ Cerrado } & $0-5$ & 2 & 7 & 13 & 20 & 4 & 46 & 12 & 42 & clayey \\
\hline & $5-10$ & 1 & 5 & 12 & 22 & 3 & 43 & 13 & 44 & clayey \\
\hline & $10-15$ & 2 & 4 & 10 & 21 & 4 & 41 & 10 & 49 & clayey \\
\hline \multirow[t]{3}{*}{ Cerradão } & $0-5$ & 1 & 8 & 25 & 40 & 6 & 80 & 4 & 16 & m-sandy \\
\hline & $5-10$ & 1 & 7 & 24 & 40 & 4 & 76 & 6 & 18 & m-sandy \\
\hline & $10-15$ & 1 & 6 & 33 & 43 & 3 & 86 & 4 & 10 & sandy \\
\hline Gallery & $0-5$ & 1 & 8 & 19 & 19 & 8 & 55 & 14 & 31 & m-clayey \\
\hline \multirow[t]{2}{*}{ forest } & $5-10$ & - & 7 & 19 & 21 & 8 & 55 & 12 & 33 & m-clayey \\
\hline & $10-15$ & - & 7 & 15 & 16 & 11 & 49 & 12 & 39 & clayey \\
\hline
\end{tabular}

vc: very coarse; c: coarse; m: medium; f: fine; vf: very fine; tot total; -: not analysed or value zero. 
Table 3. Number of seeds (seeds and fruits) in $500 \mathrm{~cm}^{3}$ soil samples (three replicates) from the cerradão, cerrado "sensu stricto"and gallery forest collected in the dry season (August) at Pedregulho, Estação Experimental de Itirapina (Itirapina, SP, Brazil) at three depths: $0-5,5-10$ and $10-15 \mathrm{~cm}$. Seeds retained in sieves with pores of $2.00,0.85$ and $0.42 \mathrm{~mm}$.

\begin{tabular}{lcrrrr}
\hline \multirow{2}{*}{ Soil sample } & $\begin{array}{c}\text { Depth } \\
(\mathrm{cm})\end{array}$ & \multicolumn{3}{c}{ Sieve pore size $(\mathrm{mm})$} & Total \\
\cline { 3 - 5 } Cerradão & $0-0$ & 11 & 23 & 12 & 46 \\
& $5-10$ & 1 & 11 & 6 & 18 \\
& $10-15$ & 1 & 8 & 3 & 12 \\
& total 0-15 & 13 & 42 & 21 & 76 \\
Cerrado & $0-5$ & 8 & 148 & 473 & 629 \\
& $5-10$ & 0 & 62 & 242 & 304 \\
& $10-15$ & 0 & 40 & 107 & 147 \\
& total 0-15 & 8 & 250 & 822 & 1080 \\
Gallery & $0-5$ & 11 & 16 & 28 & 55 \\
forest & $5-10$ & 1 & 7 & 10 & 18 \\
& $10-15$ & 0 & 7 & 6 & 13 \\
& total 0-15 & 12 & 30 & 44 & 86 \\
\hline
\end{tabular}

For the dry season, in the cerradão soil few seedlings appeared and no seedlings of monocotyledons could be seen in the samples collected at 10-15 cm deep. More seedlings appeared in the samples from the cerrado and gallery forest. In the cerrado more seedlings emerged from the superficial soil than at 5-10 and 10-15 cm deep; in the latter depth there was a reduction in the number of seedlings. Both dicotyledon and monocotyledon species appeared at the three depths collected. The number of dicotyledon species decreased with depth. In the gallery forest the number of seedlings decreases with depth of the sample. No new seedlings emerged after 60 days of observation and all the results presented are after 83 days of observation. In the cerradão the emerged seedlings belonged to two species, in the cerrado to 10 and in the gallery forest to 11 different species. There is a strong discrepancy between number of seeds in the bank and number of germinated seeds in the three areas studied: cerradão, cerrado and gallery forest.

Number of seeds and seedlings in the soil bank in the rainy season - The number of seeds in the soil samples collected in the rainy season is shown in table 4. Again the cerrado soil bank is very rich in seeds. The number is smaller in the cerradão and gallery forest when compared to the number in the cerrado. The number of seeds decreases with increasing depth in the cerrado, cerradão but not in the gallery forest. In cerrado and gallery forest, the majority of seeds are small, being retained in the $0.42 \mathrm{~mm}$ pore sieve. The picture is different for the cerradão: more seeds were retained in the $2.00 \mathrm{~mm}$ pore sieve. Few seeds larger than $2.00 \mathrm{~mm}$ were present in the cerrado and gallery forest.

Table 5 shows that the number of emerged seedlings during 83 days was similar for cerradão, cerrado and gallery forest. The results for the cerradão show more emerged seedlings in the samples collected at $5-10 \mathrm{~cm}$ deep. The number of seedlings in the cerrado and gallery forest decreases with depth of the sample. There is a strong discrepancy between total number of emerged seedlings from the soil samples (28 in cerradão, 31 in the cerrado and 27 in the gallery forest) and the number of seeds found in the soil banks (tables 3 and 4). More dicotyledon than monocotyledon species appeared at the three depths collected.

Table 4. Number of seeds (seeds and fruits) in $500 \mathrm{~cm}^{3}$ soil samples (three replicates) from the cerradão, cerrado "sensu stricto" and gallery forest collected in the rainy season (February) at Pedregulho, Estação Experimental de Itirapina (Itirapina, SP, Brazil) at three depths: $0-5,5-10$ and $10-15 \mathrm{~cm}$. Seeds retained in sieves with pores of $2.00,0.85$ and $0.42 \mathrm{~mm}$.

\begin{tabular}{lcrrrr}
\hline \multirow{2}{*}{ Soil sample } & $\begin{array}{c}\text { Depth } \\
(\mathrm{cm})\end{array}$ & \multicolumn{3}{c}{ Sieve pore size $(\mathrm{mm})$} & Total \\
\cline { 3 - 5 } Cerradão & $0-5$ & 40 & 0.85 & 0.42 & \\
& $5-10$ & 9 & 5 & 5 & 12 \\
& $10-15$ & 1 & 2 & 1 & 5 \\
& total $0-15$ & 50 & 19 & 23 & 93 \\
Cerrado & $0-5$ & 27 & 65 & 136 & 227 \\
& $5-10$ & 45 & 27 & 111 & 182 \\
& $10-15$ & 12 & 54 & 113 & 179 \\
& total $0-15$ & 84 & 146 & 360 & 588 \\
Gallery & $0-5$ & 16 & 17 & 14 & 47 \\
forest & $5-10$ & 11 & 22 & 82 & 115 \\
& $10-15$ & 2 & 8 & 26 & 36 \\
& total $0-15$ & 29 & 47 & 122 & 198 \\
\hline
\end{tabular}




\section{Discussion}

The physical extraction of seeds from the soil and emergence of seedlings from soil are used to estimate seed bank composition (Brown 1992). When relative differences are the concern, both methods can detect differences (Ball \& Miller 1989). Both methods were used here and the technique used to recover seeds from the soil was very efficient as shown by the use of the Celosia marker.

The occurrence and distribution of rainfall is of paramount importance in tropical environments (Stubblebine et al. 1978). In the cerrado of the "Reserva Biológica e Estação Experimental de Moji Guaçu" the majority of plants flowered in the rainy season liberating their fruits in the dry season (Mantovani \& Martins 1988). In the present work the number of seeds was much larger in the cerrado in the dry season than in the rainy season, which agrees with that information.

The analysis of the vertical structure of the seed bank is a means of evaluating which seeds arrived before and which later, for example when an agricultural field was abandoned (Kiirikki 1993), but this was not our concern here. Also an idea of the nutritional status of the soil can be inferred by the study of different depths of the seed bank and here in the different communities studied the total number of seeds and the number of viable seeds decreased with increased

Table 5. Number of seedlings of dicotyledon (Dicot.) species and monocotyledon (Monocot.) species emerged after 83 days from the beginning of the germination experiment in $500 \mathrm{~cm}^{3}$ soil samples collected in the dry season (August) and in the rainy season (February) at 0-5, 5-10 and 10-15 cm deep in the cerradão, cerrado "sensu stricto"and gallery forest at Pedregulho, Estação Experimental de Itirapina (Itirapina, SP, Brazil).

\begin{tabular}{lrrrrrrr}
\hline \multirow{2}{*}{ Samples } & \multicolumn{5}{c}{ Number of seedlings } & Total \\
\cline { 2 - 6 } & $0-5 \mathrm{~cm}$ deep & $5-10 \mathrm{~cm}$ deep & \multicolumn{1}{c}{$10-15 \mathrm{~cm}$ deep } \\
Dicot. Monocot. & Dicot. Monocot. & Dicot. Monocot. \\
\hline Cerradão & 3 & 3 & 2 & 1 & 3 & 0 & 12 \\
Cerrado & 17 & 5 & 12 & 7 & 5 & 6 & 52 \\
Gallery forest & 16 & 6 & 11 & 1 & 8 & 1 & 43 \\
& & & rainy season & & & \\
Cerradão & 6 & 1 & 16 & 1 & 3 & 1 & 28 \\
Cerrado & 9 & 4 & 10 & 0 & 8 & 0 & 31 \\
Gallery forest & 10 & 6 & 6 & 1 & 4 & 0 & 27 \\
\hline
\end{tabular}

depth. The decrease in the number of viable seeds with increasing depth reflects two things: the decrease in number of seeds (tables 3 and 4) and the decrease in nutrients of the deeper layers of the soils used (table 1). In relation to fern spores bank, very few viable spores are present on the deeper soil samples and the gametophytes develop more slowly than those on samples collected near the surface, probably due to the nutritional deficiency of the deeper soil samples, among other reasons (Lindsay \& Dyer 1990).

The number of viable seeds in the three areas studied here (independently of depth of the layer studied) was very small. This is not surprising as in general seed banks are occasionally small or lacking in some plant communities like forests (Frank \& Safford 1970, Johnson 1975) whereas in abandoned agricultural sites seed banks are large (Shiro \& Kanda 1996). For example, the number of viable seeds found in the present study is very small when compared with the number of 200 viable seeds in $1000 \mathrm{~cm}^{3}$ of soil found by Kiirikki (1993) in an agricultural site in Finland. Even though the method for counting seedlings produced a very low number of seeds for the three areas studied this is considered by Gross (1990) a good method for assessing viable seeds in the bank.

The seeds and seedlings could not be identified to species level. Although the vascular flora of the "Estação Experimental de Itirapina" has been well studied (Gianotti \& Leitão-Filho 1992), there is no mention about morphological characteristics of seeds or seedlings in this area or in any other natural communities in Brazil, as for example the cerrado. However, we could identify a group of seeds belonging to different species of Miconia and Tibouchina (Melastomataceae). In both seasons, this was the most common group of seeds found in the soil samples and was far more frequent in the soil from the cerrado than in the other sites, the number decreasing with increased depth. Garcia (1995) dealing with weeds was able to produce a list of species whose viable seeds were present in the bank in the maize field studied.

There is no doubt of the importance of the seed bank as a means to recover the cerrado "sensu stricto", cerradão and gallery forest vegetation. But it must be remembered that vegetative reproduction can be as effective. In northern Japan the revegetation was a result of vegetative reproduction rather than regeneration from the seed bank (Shiro \& Kanda 1996). 
Acknowledgements - Are due to CNPq for financial support. Thanks are also due to Alessandra M. Lopes and Daniela Trevizan for technical assistance.

\section{References}

ARCHIBOLD, O.W. 1981. Buried viable propagules in native prairie and adjacent agricultural sites in central Saskatchewan. Can. J. Bot. 59:701-706.

BALL, D.A. \& MILLER, S.D. 1989. A comparison of techniques for estimation of arable soil seed bank and their relationship to weed flora. Weed Res. 29:365-373.

BENNINGTON, C.C., MCGRAW, J.B. \& VAVREK, M.C.1991. Ecological genetic variation in seed banks: II. Phenotypic and genetic differences between young and old subpopulations of Luzula parviflora. J. Ecol. 79:627-643.

BENOIT, D.L., KENKEL, N.C. \& CAVERS, P.B.1989. Factors influencing the precision of soil seed bank estimates. Can. J. Bot. 67:2883-2840.

BERGE, G. \& HESTMARK, G. 1997. Composition of seed banks of roadsides, stream verges and agricultural fields in southern Norway. Ann. Bot. Fennici 34:77-90.

BROWN, D.1992. Estimating the composition of a forest seed bank: a comparison of the seed extraction and seedling emergence methods. Can. J. Bot. 70:1603-1612.

COFFIN, D.P. \& LAVENROTH, W.K.1989. Spatial and temporal variation in seed bank of a semi-arid grassland. Am. J. Bot. 76:53-58.

COUTINHO, L.M., VUONO, Y.S. DE, LOUSA, J.S. 1982. Aspectos ecológicos do fogo no cerrado. IV. A época da queimada e a produtividade primária líquida epigéia do estrato herbáceo subarbustivo. Revta brasil. Bot. 5:37-41.

EITEN, G. 1972. The cerrado vegetation of Brazil. Bot. Rev. 38:201-341.

FELIPPE, G.M. \& DALE, J.E. 1990. The effects of phosphate supply on growth of plants from the Brazilian cerrado: experiments with seedlings of the annual weed, Bidens gardneri Baker (Compositae) and the tree, Qualea grandiflora Mart. (Vochysiaceae). Oecologia 82:81-86.

FRANK, R.M. \& SAFFORD, L.O. 1970. Lack of viable seeds in the forest floor after clear cutting. J. of Forestry 68:776-778.

GARCIA, M.A. 1995. Relationships between weed community and soil seed bank in a tropical agroecosystem. Agric. Ecosyst. \& Environ. 55:139-146.

GIANOTTI, E. \& LEITÃO-FILHO, H.F. 1992. Composição florística do cerrado da Estação Experimental de Itirapina (SP).In Anais do VIII Congresso da SBSP (R. Sharif, ed). SBSP, Campinas, p.21-25.
GRAHAM, D.J. \& HUTCHINGS, M.J. 1988. Estimation of the seed bank of a chalk grassland established on former arable land. J. Appl. Ecol. 25:241-252.

GRASTRÖM, A.1988. Seed banks at six open and afforested heathland sites in southern Sweden. J. Appl. Ecol. 25:297306

GROSS, K.L.1990. A comparison of methods for estimating seed numbers in the soil. J. Ecol. 78:1079-1093.

HENDERSON, C.B., PETERSEN, K.E. \& REDAK, R.A. 1988. Spatial and temporal patterns in the seed bank and vegetation of a desert grassland community. J. Ecol. 76:717-728.

HOWE, C.D. \& CHANCELLOR, R.J. 1983. Factors affecting the viable seed content of soils beneath lowland pastures. J. Appl. Ecol. 20:915-922.

JOHNSON, E.A.1975. Buried seed populations in the subarctic forest of Great Slave Lake, Northwest territories. Can. J. Bot. 53:2933-2941.

KIIRIKKI, M. 1993. Seed bank and vegetation succession in abandoned fields in Karkali Nature Reserve, southern Finland. Ann. Bot. Fennicci 30:139-152.

LINDSAY, S. \& DYER, A.F. 1990. Fern spore banks: implications for gametophyte establishment. In Taxonomia, biogeografia y conservación de pteridófitos (J. Rita, ed.). Societat d'Historia Natural de les Illes Balears-Institut Menorqui d' Estudis, Palma de Mallorca, p. 243-253.

MANTOVANI, W. \& MARTINS, F.R. 1988. Variações fenológicas das espécies do cerrado da Reserva Biológica de Moji Guaçu, estado de São Paulo. Revta brasil. Bot. 11:101-112.

PRICE, M.V. \& REICHMAN, O.J. 1987. Distribution of seeds in Sonoran desert soils: implications for heteromyid rodent foraging. Ecology 68:1797-1811.

ROBERTS, H.A. 1981. Seed banks in soils. Adv. Appl. Biol. 6: $1-55$.

SHIRO, T. \& KANDA, F. 1996. Revegetation patterns and seed bank structure on abandoned pastures in northern Japan. Amer. J. Bot. 83:1422-1428.

STUBBLEBINE, W., LANGENHEIM, J.M. \& LINCOLN, D. 1978. Vegetative response to photoperiod in the tropical leguminous tree Hymenaea courbaril L. Biotropica 10:1829.

THOMPSON, K. 1987. Seeds and seed banks. New Phytol. 106:23-34.

VILLIERS, A.J. DE, VAN ROOYEN, M.W. \& THERON, G.K. 1994. Comparison of two methods for estimating the size of the viable seed bank of two plant communities in the Strandveld of the wet coast, South Africa. S. Afr. J. Bot. 60:81-84

WESSON, G. \& WAREING, P.F. 1969. The role of light in the germination of naturally occurring population of buried weed seeds. J. Exp. Bot. 20:402-413. 